\title{
PARTICIPATIVNI PRISTOP PRI PRIPRAVI UPRAVLJAVSKIH NAČRTOV NA PRIMERU IZBRANIH GOZDNIH HABITATNIH TIPOV IN ŽIVALSKIH VRST OB MURI
}

\section{A PARTICIPATORY APPROACH TO THE DRAFTING OF MANAGEMENT PLANS BASED ON THE EXAMPLE OF SELECTED FOREST HABITAT TYPES AND ANIMAL SPECIES ALONG THE MURA RIVER}

\author{
Andreja FERREIRA ${ }^{1}$, Petra GROŠELJ ${ }^{2}$, Špela PLANINŠEK ${ }^{3}$ \\ (1) Gozdarski inštitut Slovenije, andreja.ferreira@gozdis.si \\ (2) Univerza v Ljubljani, Biotehniška fakulteta, Oddelek za gozdarstvo in obnovljive gozdne vire, petra.groselj@bf.uni-lj.si \\ (3) Gozdarski inštitut Slovenije, spela.planinsek@gozdis.si
}

\section{IZVLEČEK}

Evropska komisija za območja Natura 2000 priporoča izdelavo upravljavskih načrtov, ki vključujejo lokacijsko specifične cilje in na njih temelječe ukrepe ohranjanja narave. Da bi se izognili morebitnim poznejšim konfliktom, je treba v proces pravočasno in smiselno vključiti vse zainteresirane deležnike. V okviru projekta GoForMura sta bila kot vzorčni primer oblikovana upravljavska načrta za gozdni območji Natura 2000 na študijskih območjih Gornja Bistrica in Murska šuma v Prekmurju. Posebno težo v procesu nastajanja prvih tovrstnih dokumentov je imelo sodelovanje zainteresiranih deležnikov, še posebej lastnikov oz. upravljavcev gozdov.

Ključne besede: participacija, gozdnogospodarsko načrtovanje, upravljanje, Natura 2000, Mura, gozd, večkriterijsko odločanje, SMART

\begin{abstract}
For Natura 2000 areas, the European Commission proposes the drafting of management plans that include site-specific objectives and conservation measures based thereon. In order to avoid potential subsequent conflicts, the process needs to involve all stakeholders early on and in a sensible manner. In the framework of the project GoForMura, management plans for the Natura 2000 forest sites in the study areas of Gornja Bistrica and Murska Šuma in the Prekmurje region were drafted as model plans. The participation of stakeholders, in particular forest owners and managers, was given special attention in the drafting of what were the first such documents.
\end{abstract}

Key words: participation, forest planning, management, Natura 2000, Mura, forest, multi-criteria decision making, SMART

1 UVOD

1 INTRODUCTION

$\mathrm{Za}$ trajnostno gospodarjenje $\mathrm{z}$ gozdom sta pomembna sodelovanje in podpora številnih deležnikov (Chambers in Beckley, 2003). Ti v proces odločanja prispevajo svoje znanje, izkušnje, poglede in preference. Njihova participacija je pomembna, saj se s tem poveča razumevanje problema, implementira lokalno znanje in izboljša javno razumevanje in podpora gospodarjenju z gozdom (Sheppard in Achiam, 2004; Sheppard in Meitner, 2005; Acosta in Corral, 2017). Deležnike običajno predstavljajo zainteresirane organizacije, skupine in posamezniki, ki jih zanima aktivno sodelovanje pri odločanju (Rowe in Frewer, 2000). Pri gospodarjenju z gozdom so to v prvi vrsti lastniki gozdov in strokovni delavci (gozdarji), poleg njih pa tudi vladne institucije, nevladne organizacije, lokalne skupnosti, lovska združenja, okoljevarstveniki in drugi.

Deležniki so vključeni v proces odločanja na različne načine, njihovo stopnjo vključenosti pa lahko merimo z lestvico odločanja (Macpherson, 2004). Vključenost lahko variira od nesodelovanja do popolnega nadzora deležnikov nad procesom odločanja.

Participativni pristop pri odločanju o gospodarjenju z gozdom je bil doslej v prakso uveden z omejenim uspehom. Glavni težavi sta nizka raven javnega zadovoljstva glede realizacije pobud deležnikov ter nepripravljenost deležnikov za sodelovanje (Sheppard in 
Meitner, 2005). Strokovnjaki pogosto preveč dominirajo v procesu odločanja (Kakoyannis, 2001), medtem ko drugi deležniki niso slišani (Beierle in Cayford, 2002).

Sodelovanje deležnikov je bilo aktualno tudi v procesu vzpostavljanja omrežja Natura 2000, evropskega ekološkega omrežja, namenjenega ohranjanju biotske raznovrstnosti, ki je bilo oblikovano na temelju Direktive o pticah in Direktive o habitatih. Ker postopek posvetovanja, ki bi ga bilo treba izvesti za izbiro območij, $\mathrm{v}$ direktivah ni podrobno določen, so bili postopki v državah članicah precej različni in odvisni od njihovih upravnih sistemov. $\mathrm{V}$ nekaterih državah so bile opravljene podrobne razprave $\mathrm{z}$ lastniki in uporabniki, v drugih pa je bilo posvetovanje z zainteresiranimi stranmi omejeno ali ga sploh ni bilo. V nekaterih državah članicah je to bilo sporno, pojavila so se različna upravna in pravna izpodbijanja, ki so povzročila zamude pri predložitvi predlogov. Vendar Evropska komisija za področje varstva narave v tej fazi ni sodelovala, niti ni imela pooblastil za posredovanje v zvezi z različnimi postopki v državah članicah (European Commission, 2020).

V Sloveniji se je proces vzpostavljanja omrežja Natura 2000 začel s pristopnimi pogajanji za vstop v EU. Boh (2005) ugotavlja, da je bil proces zaznamovan z visoko stopnjo centraliziranosti ter tehnokratsko usmerjenim postopkom določanja. V času določanja območij s strani ministrstev, strokovno-tehničnih delovnih skupin ter komunikacijske delovne skupine podatki o predvidenih območjih Natura 2000 niso bili dostopni potencialnim deležnikom in zato le-ti niso bili seznanjeni z vključitvijo svojega ozemlja v območja Natura 2000 vse do konca postopka, širši nasprotni interesi pa niso bili jasno izraženi.

Pri vzpostavitvi območij Natura 2000 v Sloveniji torej ni bil uporabljen participativni pristop, s čimer so bile zamujene številne prednosti, med katerimi so: povečanje zavedanja javnosti o pomenu gospodarjenja z zemljišči, povečanje zaupanja v institucije, v sam proces odločanja in njegovo rešitev, izogibanje in reševanje konfliktov med deležniki, širjenje informacij in vključevanje lokalnega znanja, različnih vidikov in preferenc v model odločanja (Hiltunen in sod., 2009). Seveda ima vključevanje deležnikov tudi pomanjkljivosti, predvsem večjo porabo časa in stroškov (Reed, 2008).

Sedemnajst let po vzpostavitvi omrežja Natura 2000 lastniki zemljišč na teh območjih pogosto še vedno niso aktivno vključeni v sprejemanje odločitev o gospodarjenju z njimi, po drugi strani pa so izpostavljeni omejitvam, ki jih prinašajo omenjena varstvena območja. Stališče Evropska komisije je, da izpolnjeva- nje Nature 2000 ne more obiti lastnikov in upravljalcev zemljišč, zato je njihova participacija že v začetnih fazah odločanja ključnega pomena (European Commission, 2015). Aktivni lastniki gozda poznajo svojo lastnino, imajo svoje upravljavske cilje in igrajo ključno vlogo pri oblikovanju in uresničevanju upravljavskih ukrepov v svojih gozdovih, zato so ključni partnerji pri razvoju in uspešni implementaciji Nature 2000.

Za ohranjanje gozdnih območij Natura 2000 je Slovenija sprejela generalno rešitev - sektorske načrte upravljanja, v katere se vgrajujejo naravovarstvene smernice. V skladu z operativnim programom upravljanja območij Natura 2000 temu ustrezajo gozdnogospodarski načrti gozdnogospodarskih enot (krajše GGN GGE), saj imajo pristojnost določati izpolnjevanje varstvenih ukrepov za zagotavljanje ugodnega stanja gozdnih habitatnih tipov in vrst, vezanih na gozdne ekosisteme (Bibič, 2007). Čeprav se navedena oblika dopolnjevanja GGN z naravovarstvenimi smernicami zdi dobra rešitev, načrtovalske izkušnje in sodobna načrtovalska teorija tega ne podpirajo povsem. Najpomembnejši pomanjkljivosti načrtov sta premalo definirana namembnost načrtov in pomanjkanje konkretnih informacij. Poleg tega so načrti izdelani z metodo hierarhičnega vodenja od zgoraj navzdol in s pasivno participacijo, pri kateri lastniki gozdov in deležniki nimajo pomembnejšega vpliva na oblikovanje ciljev in usmeritev (Kovač in sod., 2017).

V okviru projekta GoForMura je bil razvit koncept upravljavskih načrtov za gozdna območja Natura 2000. Izdelana sta bila dva predloga upravljavskih načrtov za študijski območji Gornja Bistrica in Murska šuma. Predlagana upravljavska načrta sta glede na svojo obliko in vsebino lahko uporabljena na več načinov: kot samostojna dokumenta, kot priloga GGN GGE, lahko pa se njuna vsebina vključi tudi v obstoječi GGN GGE (Kovač in sod., 2017). Pri izdelavi predlogov upravljavskih načrtov je bil velik poudarek na participativnem pristopu (več delavnic, predstavitve na spletni strani projekta GoForMura). Lastnika (upravljavca) gozdnih zemljišč sta skupaj z drugimi deležniki vseskozi aktivno sodelovala pri zasnovi načrtov, strinjanje z vsebino pa sta izrazila s podpisom zapisnika (Kovač in sod., 2017).

Na delavnicah projekta GoForMura smo želeli, da deležniki podajo svoje želje, mnenja in predloge neposredno izdelovalcem upravljavskega načrta, saj so v tej fazi velike možnosti vpliva na sprejemanje odločitev. Z mnenji in konstruktivnimi pripombami deležnikov sta upravljavska načrta pridobila na legitimnosti, saj so vanju vključene vsebine, ki jih imajo deležniki za pomembne. 


\section{METODE}

\section{METHODS}

\section{1 Študijsko območje}

2.1 Study area

V Sloveniji je reka Mura s svojim obvodnim svetom v celoti vključena v območje Natura 2000 tako po Direktivi o habitatih kot po Direktivi o pticah. Pečat krajini dajejo poplavni in nižinski gozdovi, ki so prilagojeni izmenjavanju poplav in sušnih obdobij in so pomemben življenjski prostor številnih rastlinskih in živalskih vrst. Pritiski s strani kmetijstva, urbanizacije, graditve infrastrukture, klimatskih sprememb ter pojava bolezni in škodljivcev imajo zelo negativne vplive na poplavne gozdove ob Muri in posledično na tam prisotne živalske vrste. Predmet raziskave sta bila gozdna habitatna tipa 91E0 - Obrečna vrbovja, jelševja in jesenovja ter 91F0 - Poplavni hrastovo-jesenovi-brestovi gozdovi, katerih ohranitveno stanje je bilo ocenjeno kot slabo (U2-) (ZRSVN 2013, 2019; Kutnar in Marinšek, 2016). Stanje gozdov se je začelo slabšati z regulacijami Mure in hidromelioracijami kmetijskih zemljišč v drugi polovici 20. st., ki so povzročili znižanje podtalnice. To je poslabšalo vitalnost drevja in možnost njihovega preživetja (Levanič, 1993; Čater, 2001). Še dodatno se stanje slabša zaradi onesnaževanja podtalnice in zaradi rastlinskih bolezni (Kelenc, 2008). Stanje se slabša tudi zaradi posekov avtohtonih drevesnih vrst, sajenja hitrorastočih tujerodnih drevesnih vrst (kloni črnega topola ...), sprememb naravnih/polnaravnih gozdov v kmetijske površine, širjenja tujerodnih invazivnih rastlinskih vrst, bolezni ter klimatskih sprememb (naraščanje temperatur, zmanjševanje količine padavin, ekstremni vremenski pojavi). Vse to vpliva tudi na poslabševanje ohranitvenega stanja tam prisotnih živalskih vrst. Med njimi je posebno skrb treba nameniti vrstam Natura 2000, ki so v neugodnem stanju in je njihov nadaljnji obstoj ogrožen. V raziskavi smo se tako osredotočili tudi na dve dvoživki, tri saproksilne hrošče, vidro in evropskega bobra, katerih ohranitveno stanje je bilo neugodno, ter pet vrst ptic, katerih ohranitveno stanje je bilo do monitoringa neznano.

\subsection{Izbira ukrepov za izboljšanje ohranitvenega} stanja gozdnih habitatnih tipov in habitatov živalskih vrst

2.2 The selection of measures for improving the conservation status of forest habitat types and animal habitats

Ker sta za ohranjanje narave ključnega pomena sodelovanje ter podpora splošne in strokovne javnosti ter še posebej lastnikov zemljišč, smo v raziskavi veliko pozornosti posvetili delu z deležniki. V okviru projekta smo imeli tri strokovne delavnice za zainteresirano javnost, med njimi eno terensko ter zaključno konferenco. Končni namen tovrstnih delavnic ni le legalnost, temveč visoka legitimnost izdelanih raziskav.

Rezultat prve delavnice projekta, ki je potekala oktobra 2015, je bila določitev glavnih skupin ukrepov in pripadajočih ukrepov za izboljšanje ohranitvenega stanja tam prisotnih gozdnih habitatnih tipov in habitatov živalskih vrst. Cilj te delavnice je bil intenzivno zbiranje mnenj, potreb, želja deležnikov in usklajevanju le-teh za potrebe priprave načrta upravljanja. Poleg identifikacije vseh deležnikov in določitve najbolj obremenjenih gozdnih območij so udeleženci delavnice poudarili tudi ključne težave sedanjega upravljanja $\mathrm{z}$ gozdovi na tem območju.

Na podlagi rezultatov delavnice in tam opravljenega točkovnega rangiranja množice možnih ukrepov s strani udeležencev so se v nadaljnjo obravnavo uvrstili tisti z največjim številom točk. Strokovni sodelavci projekta smo jih smiselno razvrstili v pet skupin ukrepov (preglednica 1).

\subsection{Večkriterijska metoda}

\subsection{Multi-criteria method}

Med participativne metode uvrščamo delavnice, javna in individualna srečanja, ankete v obliki vprašalnikov ali intervjujev, v zadnjem času pa tudi e-participacijo prek spletnih platform (primer Participativne delavnice na temo obnove dolgoročnih lovsko upravljavskih načrtov ..., 2021). Tako pridobimo mnenja deležnikov, vendar so pridobljeni podatki pogosto zgolj opisni in manjkajo formalna struktura in orodja za njihovo analizo in interpretacijo (Mendoza in Prabhu, 2005). Kot uspešno se je pokazalo kombiniranje participativnega odločanja z večkriterijskimi metodami, ki omogočajo vključevanje različnih mnenj, izkušenj in preferenc $v$ proces odločanja in tudi njihovo usklajevanje (Pavlikakis in Tsihrintzis, 2003; Mendoza in Prabhu, 2006; Bryan in sod., 2010; Nordström in sod., 2010; Grošelj in sod., 2016). Večkriterijske metode dajejo več prednosti, kot so pomoč pri strukturiranju problema, formalnost odločitvenega modela, kar hkrati zagotavlja večjo transparentnost (Khadka in sod., 2013).

Participativni pristop v povezavi z večkriterijskimi metodami je bil na področju gospodarjenja z gozdovi večkrat uporabljen (Uhde in sod., 2015; Ortiz-Urbina in sod., 2019). Med njimi se najpogosteje uporabljajo analitični hierarhični proces (AHP) (Nordström, 2010; Zandebasiri in Pourhashemi, 2016; Ananda in Herath, 2003b; Huber in sod., 2019), analitični mrežni proces (ANP) (Grošelj in Zadnik Stirn, 2015), Simple MultiAttribute Rating Technique (SMART) (Nordström in sod., 2013; Pezdevšek Malovrh in sod., 2016) in Mul- 
Preglednica 1: Skupine ukrepov in njim podrejeni ukrepi za izboljšanje ohranitvenega stanja gozdnih habitatnih tipov in habitatov živalskih vrst
Table 1: Sets of measures and subordinate measures for improving the conservation status of forest habitat types and animal habitats

\begin{tabular}{|c|c|}
\hline SKUPINE UKREPOV & UKREPI \\
\hline $\begin{array}{l}\text { Ukrepi za izboljšanje ohranitvenega stanja obravnava- } \\
\text { nih živalskih vrst (naravovarstveno pomembnih vrst). }\end{array}$ & \begin{tabular}{|ll} 
& Znanstvene raziskave o ekoloških potrebah obravnavanih živalskih vrst. \\
0 & Povečanje ozaveščenosti o vplivih obravnavanih živalskih vrst. \\
0 & Določitev mirnih con in ekocelic. \\
0 & Tehnični ukrepi in strokovna podpora lastnikom pri upravljanju z bobrom. \\
0 & Izogibanje posegom v bobrove jezove in bobrišča.
\end{tabular} \\
\hline Ukrepi za obnovo gozda. & 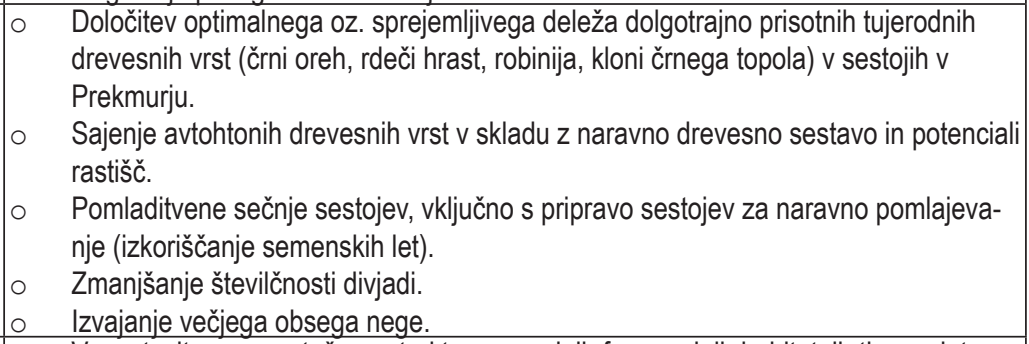 \\
\hline $\begin{array}{l}\text { Ukrepi za zagotavljanje trajnosti gozdnih habitatnih } \\
\text { tipov. }\end{array}$ & \begin{tabular}{|ll} 
& Vzpostavitev uravnotežene strukture razvojnih faz gozdnih habitatnih tipov z inten- \\
& ziviranjem uvajanja v obnovo (naravno in umetno). \\
0 & Vzpostavitev gozdnih rezervatov znotraj gospodarskega gozda. \\
0 & Uporaba terenu primerne gozdarske tehnologije. \\
0 & Znanstvene raziskave o ekoloških zahtevah gozdnih habitatnih tipov. \\
0 & Strokovna podpora lastnikom pri izpolnjevanju varstvenih ukrepov.
\end{tabular} \\
\hline $\begin{array}{l}\text { Ukrepi za izboljšanje zdravstvenega stanja ključnih } \\
\text { drevesnih vrst. }\end{array}$ & $\begin{array}{ll}\circ & \text { Zamenjava drevesnih vrst. } \\
\circ & \text { Osnovanje mešanih sestojev. } \\
\circ & \text { Sajenje rastišču najustreznejših drevesnih vrst. } \\
\circ & \text { Ohranjanje manj poškodovanih dreves (iskanje naravne odpornosti npr. pri velikem } \\
\text { in poljskem jesenu). } \\
\circ \quad \text { Zgodnje redčenje. }\end{array}$ \\
\hline Ukrepi za nadzor nad invazivnimi vrstami. & $\begin{array}{ll} & \text { Upoštevanje državne uredbe za ambrozijo. } \\
\circ & \text { Preprečevanje vnosa in širjenja invazivnih vrst, še posebej v začetni fazi širjenja } \\
& \text { (npr. Amorfa fruticosa). } \\
\circ & \text { Sajenje domačih drevesnih vrst znotraj sestojev invazivnih vrst - nato obžetev. } \\
\circ & \text { Robinija, črni oreh - sprememba statusa invazivne vrste? } \\
\circ & \text { Intenzivno obveščanje in izobraževanje javnosti o invazivnih vrstah in dobrih pra- } \\
& \text { ksah obvladovanja le-teh. }\end{array}$ \\
\hline
\end{tabular}

ti-Attribute Utility Theory (MAUT) (Ananda in Herath, 2003a). Slabost, ki jih lahko prinese uporaba večkriterijskih metod, je časovna potratnost in zapletenost metode, ki je lahko težko razumljiva za deležnike, ki se prvič srečujejo z metodo (Kangas in sod., 2006; Blagojević in sod., 2019).

V našem primeru smo za oceno pomembnosti skupin ukrepov in njim podrejenih ukrepov za izboljšanje ohranitvenega stanja gozdnih habitatnih tipov in vrst izbrali večkriterijsko metodo SMART (Edwards, 1977; von Winterfeldt in Edwards, 1986). SMART je pravzaprav družina različnih modifikacij osnovne metode (Edwards in Barron, 1994), ki temelji na razmernostni lestvici. Zanjo smo se odločili, ker je ena enostavnejših večkriterijskih metod, ki omogoča direktno primerjavo pomembnosti kriterijev. Primerna je za situacije, kjer deležniki ne morejo ali niso pripravljeni oceniti številnih in včasih težko razumljivih parnih primerjav (Kajanus in sod., 2004). Deležniki razvrstijo $n$ objektov, ki jih želijo primerjati, po pomembnosti, od najbolj pomembnega do najmanj pomembnega. Nato izberejo najvišjo možno oceno $p_{1}$ za najpomembnejši objekt, za druge objekte pa proporcionalno manjše ocene $p_{2}, \ldots, p_{n}$. Dva objekta lahko dobita tudi enaki oceni. Dobljene ocene nato še normaliziramo na interval $[0,1]$ :

$$
w_{k}=\frac{p_{k}}{\sum_{i=1}^{n} p_{i}}, k=1, \ldots, n
$$

$\mathrm{V}$ uporabi so lestvice $\mathrm{z}$ različnimi razponi (Barzilai in sod., 1997), v osnovni različici se uporabljajo vrednosti od 1 do 100 . V našem primeru smo uporabili različico $\mathrm{z}$ vrednostmi od 1 do 10 , ki je laže razumljiva tudi deležnikom, ki se še nikoli niso srečali z večkriterijskimi metodami. Za združevanje uteži deležnikov v skupinske uteži smo uporabili aritmetično sredino.

\subsection{Izvedba delavnice}

\subsection{Workshop implementation}

Priprava druge delavnice in delovnega gradiva za udeležence je trajala od januarja do aprila 2016. Pripravili smo vprašalnik za ocenjevanje petih skupin 
ukrepov in petih podrejenih ukrepov (preglednica 1) z metodo SMART. Izdelani vprašalnik smo testirali na vzorcu manjše skupine deležnikov. Po odpravi nejasnosti in časovni prilagoditvi je bil vprašalnik pripravljen za izvedbo na delavnici.

Aprila 2016 je v Srednji Bistrici potekala delavnica za širšo javnost, na kateri so nastali rezultati pričujočega članka. Osrednji namen delavnice je bilo ovrednotenje skupin ukrepov in njim podrejenih ukrepov za potrebe izdelave upravljavskih načrtov za dve gozdni študijski območji ob Muri. Raziskovalci Gozdarskega inštituta Slovenije, Zavoda za gozdove Slovenije in Inštituta LUTRA so zbranim predstavnikom različnih institucij, zavodov in zainteresiranim posameznikom predhodno predstavili dosedanje rezultate na projektnih območjih v Murski šumi in Gornji Bistrici.

Participativni del delavnice je bil razdeljen na dva vsebinska sklopa:

- Razgrnitev gojitvenih rešitev in zbiranje predlogov na detajlni sestojni karti.

- Vrednotenje skupin ukrepov in njim podrejenih ukrepov za izboljšanje ohranitvenega stanja gozdnih habitatnih tipov in habitatov živalskih vrst ob Muri z uporabo metode SMART.

Udeleženci delavnice so bili ob prihodu uvrščeni v eno od naslednjih skupin:
A - lovci
B - ribiči
C - gozdarji
D - raziskovalci
E - naravovarstveniki

$$
\begin{aligned}
& \text { F - čebelarji } \\
& \text { G - lastniki zemljišč } \\
& \text { H - zainteresirana javnost }
\end{aligned}
$$

Za potrebe intenzivne izmenjave mnenj so bile delovne skupine sestavljene iz predstavnikov različnih skupin (lovci, gozdarji, lastniki zemljišč, naravovarstveniki,...). Ker se je delavnice udeležil zgolj en lovec, smo njegove rezultate obdelali skupaj z rezultati gozdarjev. Prav tako sta bila na delavnici navzoča samo dva naravovarstvenika, zato smo njune odgovore pridružili skupini zainteresirane javnosti. Ribiči na delavnici žal niso imeli svojega predstavnika, čebelarji pa so se udeležili le popoldanskega programa in $\mathrm{v}$ anketo prav tako niso bili vključeni.

Uvod v 2. točko delavnice smo opravili tako, da smo namen, zgradbo vprašalnika in metodo ocenjevanja predstavili udeležencem, jim razdelili anketne vprašalnike ter jim bili na voljo za morebitna pojasnila pri izpolnjevanju vprašalnika. Vprašalnik je izpolnilo 30 udeležencev delavnice, od tega 12 lovcev in gozdarjev $(A+C), 7$ raziskovalcev (D), 7 naravovarstvenikov in zainteresirane javnosti $(\mathrm{E}+\mathrm{H})$ in 4 lastniki zemljišč (G). V skupnih rezultatih smo upoštevali, da so vsi deležniki enako pomembni.

\section{REZULTATI}

\section{RESULTS}

Udeleženci delavnice so najvišjo podporo $(23,4 \%)$ namenili skupini ukrepov za obnovo gozda (slika 1), zato jim bomo v članku namenili največ pozornosti. Z $20 \%$ sta sledili skupini ukrepov za izboljšanje zdra-

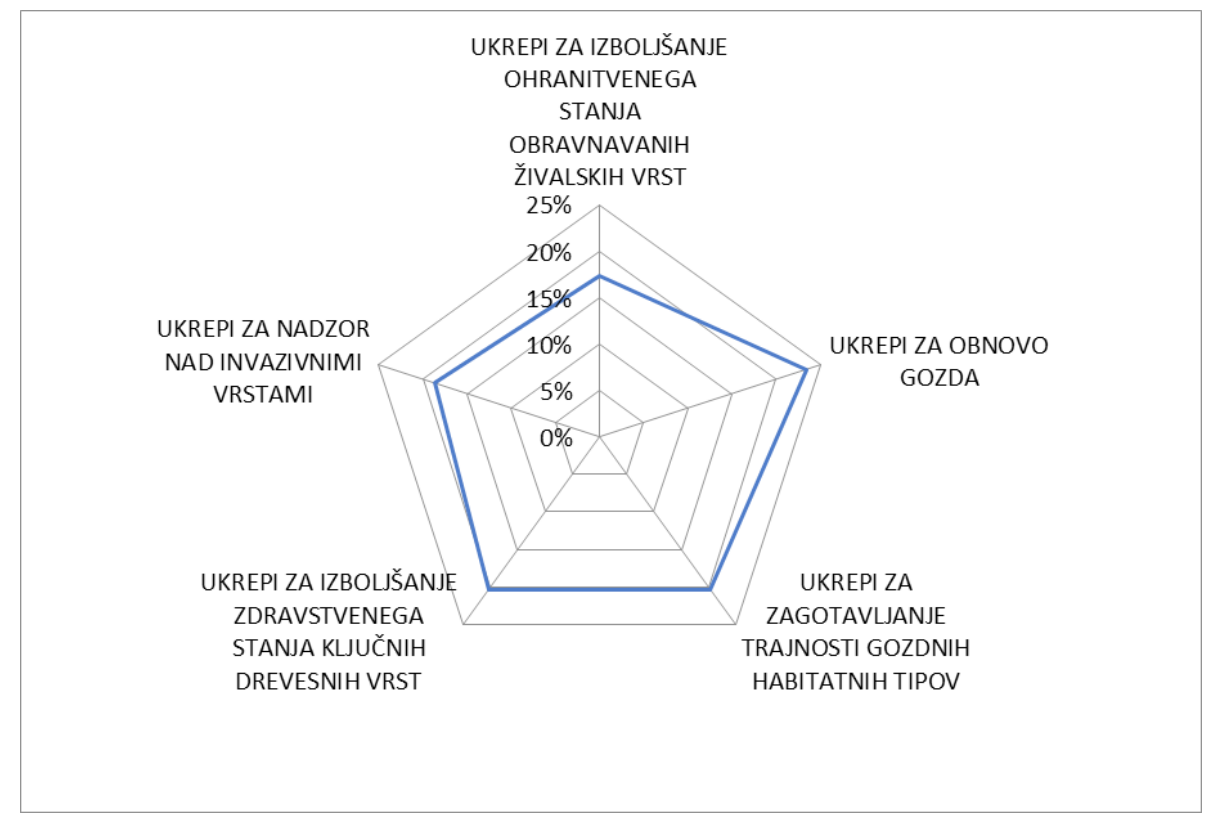

Slika 1: Podpora deležnikov različnim skupinam ukrepov

Fig. 1: Support for different groups of measures by stakeholders 


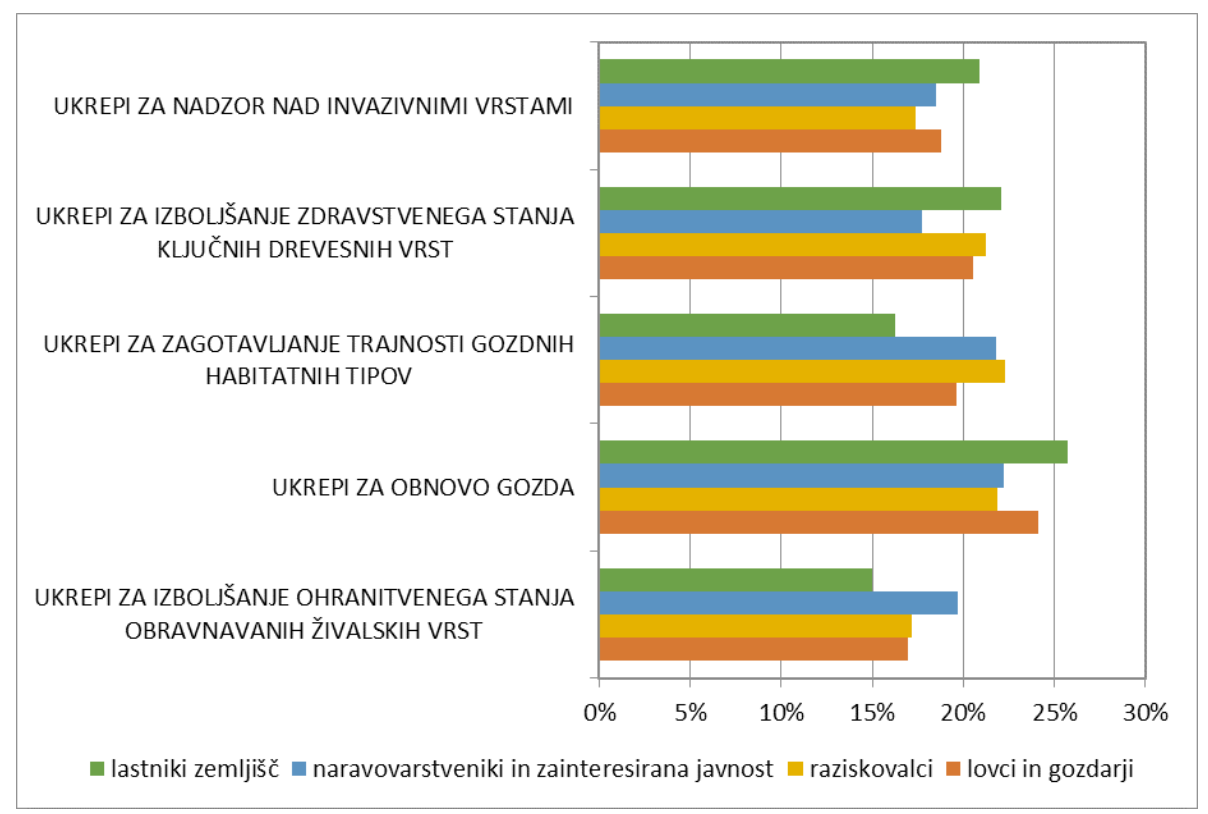

Slika 2: Podpora različnih skupin deležnikov ukrepom za obnovo gozda

vstvenega stanja ključnih drevesnih vrst in ukrepov za zagotavljanje trajnosti gozdnih habitatnih tipov. Skupina ukrepov za nadzor nad invazivnimi rastlinami je dobila $18 \%$ podpore, na zadnjem mestu pa je bila s $17 \%$ skupina ukrepov za izboljšanje ohranitvenega stanja obravnavanih živalskih vrst.

Skupini ukrepov za obnovo gozda so največjo podporo namenile kar tri skupine deležnikov (slika 2), le skupina raziskovalcev je malenkost višjo prednost dala skupini ukrepov za zagotavljanje trajnosti gozdnih habitatnih tipov. Daleč največjo podporo pa so skupini ukrepov za obnovo gozda pripisali lastniki zemljišč.
Fig. 2: Support for forest restoration measures by different groups of stakeholders

Največje razlike pri podpori različnim ukrepom za obnovo gozda so opazne med skupino lastnikov zemljišč ter združeno skupino zainteresirane javnosti in naravovarstvenikov.

V skupini ukrepov za obnovo gozda (slika 3) je največjo podporo $(23,8 \%)$ dobilo sajenje avtohtonih drevesnih vrst v skladu z naravno drevesno sestavo in potenciali rastišč. Ta ukrep je dobil največjo podporo pri večini deležnikov, le pri lastnikih zemljišč je omenjeni ukrep šele na tretjem mestu.

Drugo največjo podporo je v tej skupini dobil ukrep določitve optimalnega oziroma sprejemljivega deleža

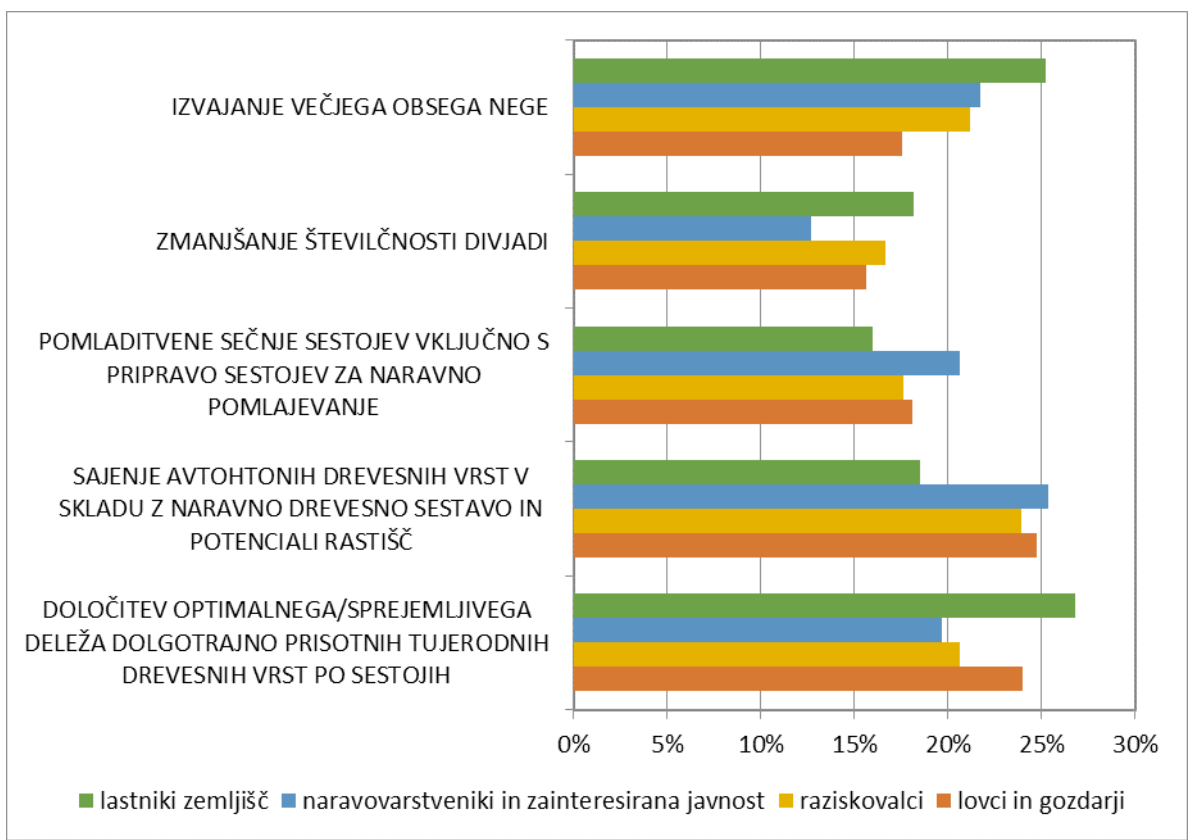

Slika 3: Ukrepi za obnovo gozda in delež podpore s strani različnih deležnikov
Fig. 3: Forest restoration measures and the share of support thereof by different stakeholders 


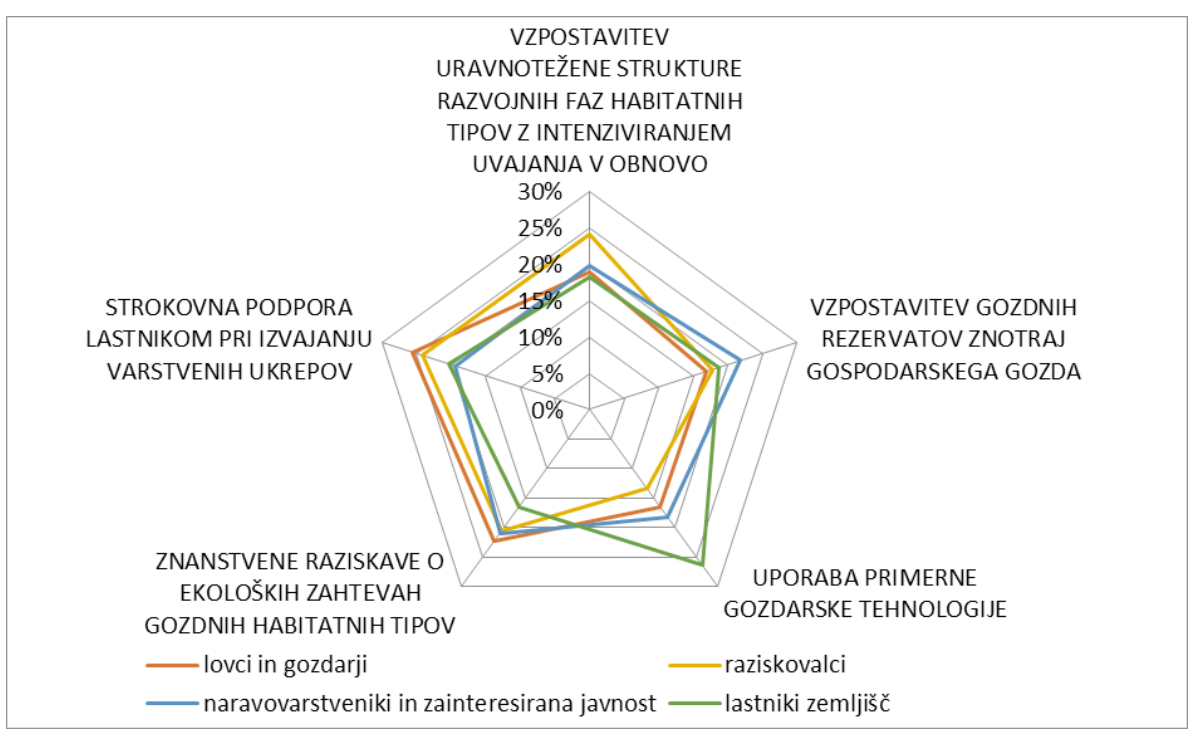

Slika 4: Skupina ukrepov za zagotavljanje trajnosti gozdnih habitatnih tipov

dolgotrajno prisotnih tujerodnih drevesnih vrst (črni oreh, rdeči hrast, robinija, topolovi kloni) v sestojih ob Muri. Iz prakse vemo, da so tujerodne drevesne vrste na tem območju precej zastopane in lastniki z njimi gospodarijo, zato ne preseneča, da so največjo podporo temu ukrepu izkazali prav oni. Sledila je skupina lovcev in gozdarjev s 23,9\%, raziskovalcev (20,6 \%) ter naravovarstvenikov in zainteresirane javnost (19,6\%).

Obseg nege gozdov na državni ravni je že vrsto let nizek. Lastniki gozdov zato veliko podporo $(25,2 \%)$ dajejo ukrepu, ki kliče k večjemu obsegu nege. Naravovarstveniki in zainteresirana javnost ter raziskovalci podpirajo ukrep z 21,7 \% in 21,1 \%, manj podpore pa je ukrepu namenila skupina lovcev in gozdarjev.

Precej manjše podpore sta bila deležna ukrepa, ki spodbujata pomladitvene sečnje sestojev, vključno s pripravo sestojev za naravno pomlajevanje (izkoriščanje semenskih let) ter zmanjšanje številčnosti divjadi. Pomladitvene sečnje najbolj podpira skupina naravovarstvenikov in zainteresirane javnosti $(20,6 \%)$, medtem ko so lastniki bolj naklonjeni ukrepu zmanjšanja številčnosti divjadi (18,1 \%), ki ji skupina naravovarstvenikov in javnosti ni naklonjena (12,7 \%).

V skupini ukrepov za zagotavljanje trajnosti gozdnih habitatnih tipov (slika 4) je največjo težo dobil ukrep strokovne podpore lastnikom pri izpolnjevanju varstvenih ukrepov, sledila sta ukrepa vzpostavitve uravnotežene strukture razvojnih faz habitatnih tipov $\mathrm{z}$ intenziviranjem uvajanja $\mathrm{v}$ obnovo (naravno in umetno) ter znanstvene raziskave o ekoloških zahtevah gozdnih habitatnih tipov. Najmanjšo podporo je dobil ukrep uporaba primerne gozdarske tehnologije, vendar ne med lastniki zemljišč, ki so mu med vsemi ukrepi iz te skupine namenili največ podpore.
Fig. 4: The set of measures for ensuring the sustainability of forest habitat types

V skupini ukrepov za izboljšanje zdravstvenega stanja ključnih drevesnih vrst so si ukrepi glede na izraženo podporo sledili v naslednjem vrstnem redu: sajenje rastišču najustreznejših drevesnih vrst, ohranjanje manj poškodovanih dreves, osnovanje mešanih sestojev, zgodnje redčenje in zamenjava drevesnih vrst. Različne skupine deležnikov so bile v odgovorih precej enotne, večje razlike so bile opazne pri zgodnjem redčenju, ki mu je izrazito najmanjšo podporo namenila združena skupina gozdarjev in lovcev, ter pri zamenjavi drevesnih vrst, ki jo daleč najmanj podpira združena skupina zainteresirane javnosti in naravovarstvenikov.

V skupini ukrepov za nadzor nad invazivnimi vrstami so kar štirje ukrepi dobili skoraj enako podporo, z malenkostno prednostjo sta največ glasov dobila ukrepa intenzivno obveščanje in izobraževanje javnosti o invazivnih vrstah in dobrih praksah obvladovanja le-teh ter preprečevanje vnosa in širjenja invazivnih vrst. Sledila sta ukrepa sajenje domačih drevesnih vrst znotraj sestojev invazivnih vrst - nato obžetev ter sprememba statusa robiniji in črnemu orehu, ki se ne bi več štela med invazivni vrsti. Bistveno manjšo podporo je dobil ukrep upoštevanje državne uredbe za ambrozijo. Največji razkorak (slika 5) je opazen pri ukrepu, ki se nanaša na status robinije in črnega oreha - lastniki zemljišč spremembo statusa močno podpirajo, v nasprotju z njimi pa mu združena skupina zainteresirane javnosti in naravovarstvenikov ni naklonjena.

V skupini ukrepov za izboljšanje ohranitvenega stanja obravnavanih živalskih vrst so največ podpore $(23,1 \%)$ dobile znanstvene raziskave o ekoloških potrebah obravnavanih živalskih vrst, malenkost manjšo $(21,9 \%)$ so deležniki namenili povečanju ozaveščenosti o vplivih obravnavanih živalskih vrst. 20,9-od- 


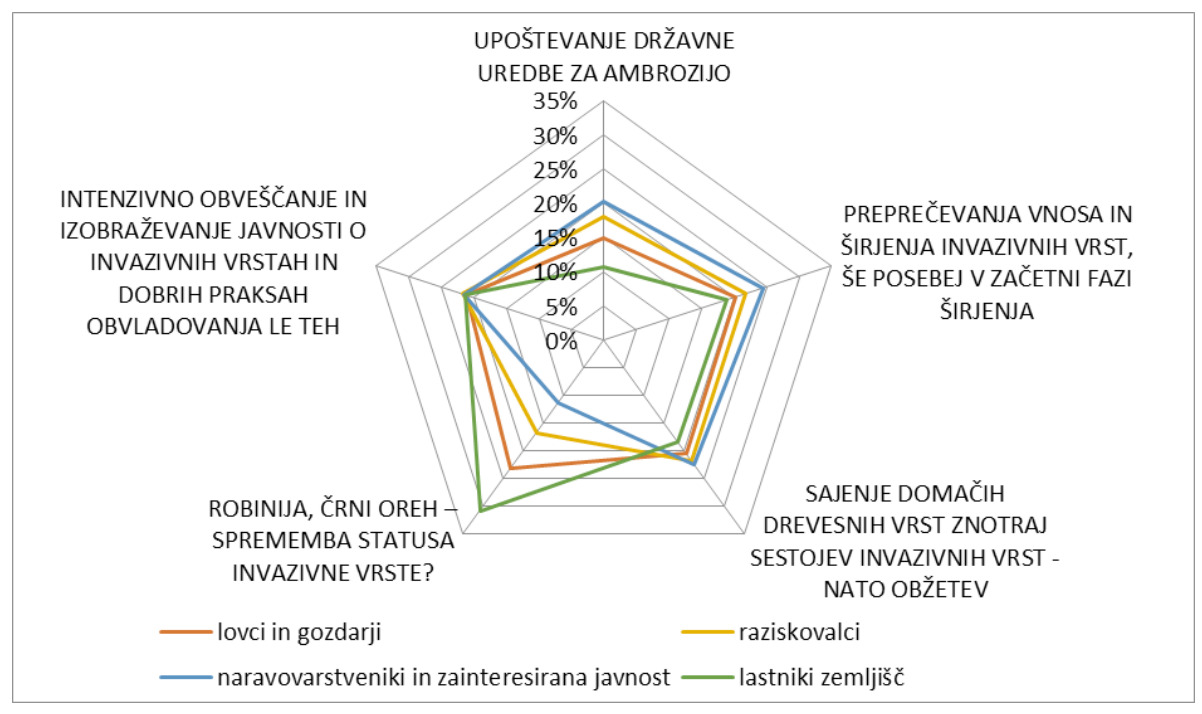

Slika 5: Skupina ukrepov za nadzor nad invazivnimi tujerodnimi rastlinami

stotno podporo je dobil ukrep določitev mirnih con in ekocelic ter 19,3-odstotno tehnični ukrepi in strokovna podpora lastnikom pri upravljanju z bobrom. Najmanj podpore $(14,7 \%)$ pa so deležniki namenili ukrepu izogibanje posegom v bobrove jezove in bobrišča. Združena skupina gozdarjev in lovcev je v primerjavi z drugimi deležniki izrazito bolj podpirala ozaveščanje o vplivih obravnavanih živalskih vrst ter obratno izrazito manj ukrep izogibanje posegom $\mathrm{v}$ bobrove jezove in bobrišča. Zanimiv razkorak je tudi pri določitvi mirnih con in ekocelic, ki jo precej enakovredno podpirajo tri skupine deležnikov na čelu z združeno skupino zainteresirane javnosti in naravovarstvenikov, precej manjšo podporo pa ima omenjeni ukrep med lastniki zemljišč.

Če obravnavamo vse naštete ukrepe skupaj (slika 6) in jim pripnemo globalne uteži, so med prvimi petimi
Fig. 5: The set of measures for controlling invasive plant alien species

ukrepi kar štirje iz skupine ukrepov za obnovo gozda, še eden iz te skupine pa je uvrščen do desetega mesta. Trije ukrepi med desetimi ukrepi z največ podpore so iz skupine ukrepov za zagotavljanje trajnosti gozdnih habitatnih tipov, po eden pa iz preostalih treh skupin obravnavanih ukrepov.

\section{RAZPRAVA IN ZAKLJUČKI \\ 4 DISCUSSION AND CONCLUSIONS}

Študijski območji ob Muri s svojimi zakonitostmi na eni in želje ter potrebe različnih deležnikov na drugi strani so od projektnih sodelavcev zahtevale premišljene poteze in obširne izmenjave mnenj. Za potrebe oblikovanja upravljavskih načrtov smo s pomočjo anketiranja in participativnih delavnic k sodelovanju pritegnili lastnike gozdov, gozdarje, lovce, raziskovalce,

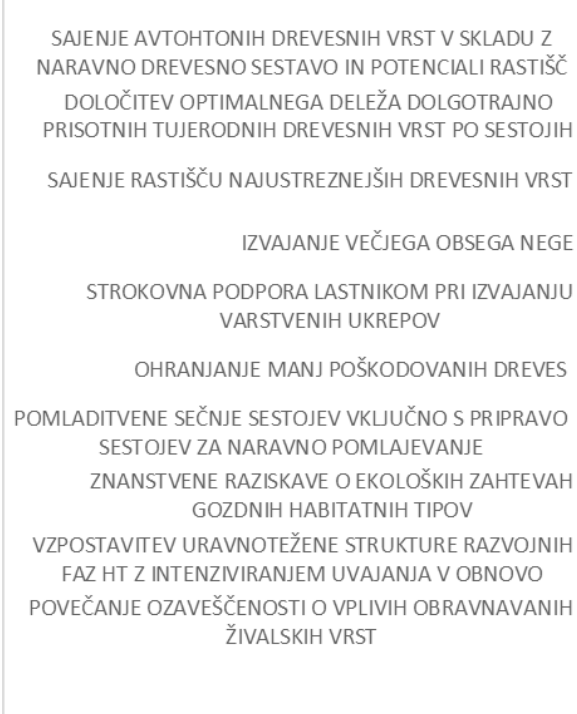

Slika 6: Deset ukrepov z največ podpore s strani vseh deležnikov

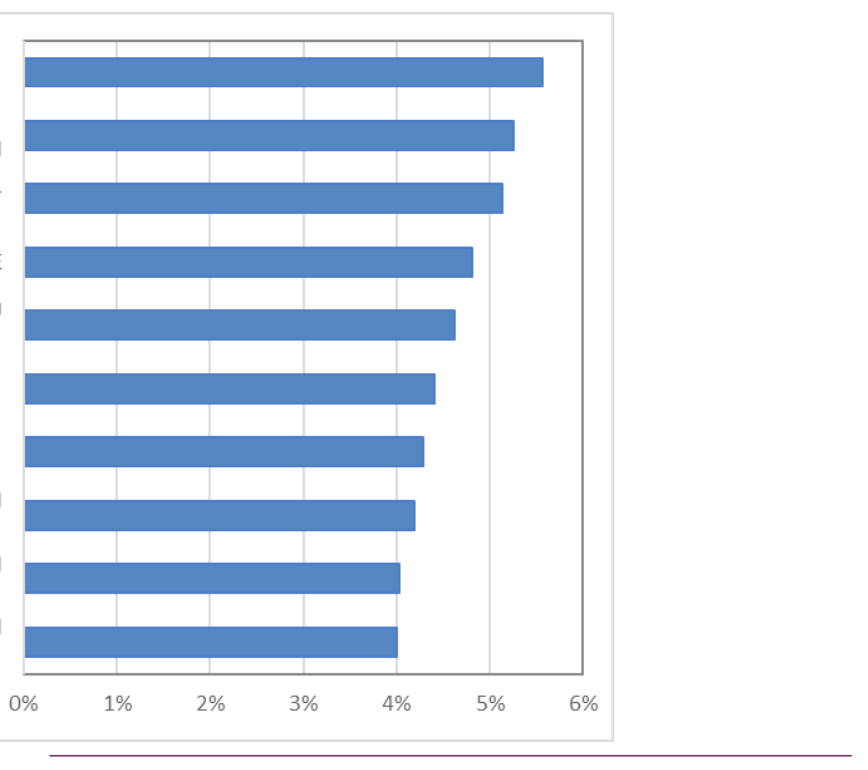

Fig. 6: Ten measures with the highest support among stakeholders 
naravovarstvenike in splošno javnost.

Povezovanje različnih strok in deležnikov včasih poraja tudi nesoglasja in nestrinjanja med njimi. $\mathrm{V}$ tem projektu smo se spopadali z zahtevnimi izzivi, npr. kako uravnovesiti trenutni razvoj gozdov in naravovarstvene smernice, kako najti ravnovesje med ekonomskimi in okoljskimi cilji gospodarjenja z gozdovi, in kdaj določeni cilji izgubijo pomen, ker kratko malo ne sodijo več v sodoben čas in prostor. Cilj participativne delavnice na Srednji Bistrici je bil tako kot pri vseh participativnih postopkih doseči soglasje/kompromis med zelo raznovrstnimi interesi deležnikov.

Problematika gozdov ob Muri je bila udeležencem delavnice predstavljena v obliki strokovnih predavanj, ki so temeljila na terenskih raziskavah projekta GoForMura. Podrobneje so bile predstavljene naslednje teme: monitoring gozdnih habitatnih tipov, invazivne tujerodne rastlinske vrste, aktualne bolezni, ki ogrožajo gozdove, monitoring bobra in vidre. Udeleženci so tako svoje znanje in izkušnje nadgradili z najnovejšimi rezultati raziskav. Sledil je participativni del delavnice, v katerem so deležniki izražali svoja stališča in poglede na razvoj gozdov ob Muri.

Pri analizi rezultatov delavnice so nas poleg absolutnih številk zanimale tudi razlike $v$ naklonjenosti petim skupinam ukrepom med različnimi skupinami deležnikov.

Rezultati izkazujejo veliko naklonjenost vseh deležnikov ukrepom za obnovo gozda, kar ne preseneča, saj so ukrepi sprejemljivi tako za lastnike gozdov kot tudi za naravovarstvenike in zainteresirano javnost. Deležniki so bili najbolj naklonjeni sajenju avtohtonih drevesnih vrst v skladu z naravno drevesno sestavo in potenciali rastišč, najmanj pa zmanjšanju številčnosti divjadi, kar kaže, da v gozdovih ob Muri divjad ne povzroča tolikšne škode kot v nekaterih drugih območjih Slovenije.

Največji razkorak pri večini ukrepov se je pokazal med interesi lastnikov gozdov na eni ter združene skupine naravovarstvenikov in zainteresirane javnosti na drugi strani. Lastniki npr. močno podpirajo določitev optimalnega oz. sprejemljivega deleža dolgotrajno prisotnih tujerodnih drevesnih vrst (črni oreh, rdeči hrast, robinija, topolovi kloni), saj so te vrste na tem območju precej zastopane in lastniki z njimi gospodarijo. Naravovarstveniki in zainteresirana javnost pa so temu ukrepu med vsemi skupinami namenili najmanjšo podporo. Rezultat je pričakovan, saj je že iz naravovarstvenih smernic razvidno, da se naravovarstvena stroka zavzema za zmanjšanje deleža dolgotrajno prisotnih tujerodnih drevesnih vrst. Skupina zainteresirane javnosti in naravovarstvenikov je tako najmanj naklonjena tudi zamenjavi drevesnih vrst za potrebe izboljšanja zdravstvenega stanja gozdov.

Lastniki veliko bolj podpirajo tudi ukrepe za izboljšanje zdravstvenega stanja ključnih drevesnih vrst kot pa naravovarstveniki in javnost. Obratno pa lastniki v primerjavi z naravovarstveniki in splošno javnostjo veliko manj podpirajo ukrepe za zagotavljanje trajnosti gozdnih habitatnih tipov in ukrepe za izboljšanje ohranitvenega stanja obravnavanih živalskih vrst. Lastniki se torej bolj zavedajo oz. opazijo zdravstvene težave ključnih drevesnih vrst, saj te lahko pomenijo velik problem $v$ razvoju gozdov.

Najmanjšo podporo se dobili ukrepi za izboljšanje ohranitvenega stanja obravnavanih živalskih vrst. Najmanj deležnikov podpira ukrep izogibanja posegov $\mathrm{v}$ bobrove jezove in bobrišča. Brez prave podpore je ostal tudi ukrep, ki bi s tehničnimi ukrepi in strokovno podporo lastnikom pomagala pri upravljanju z bobrom, največ podpore je po pričakovanjih omenjeni ukrep dobil s strani lastnikov zemljišč.

Med posameznimi ukrepi sta zelo nizko podporo prejela ukrepa izogibanje posegom $v$ bobrove jezove in bobrišča in upoštevanje državne uredbe za ambrozijo. Za prvega lahko razlago iščemo v smeri komentarjev z delavnic, ki nakazujejo, da je predvsem za lastnike obvodnih zemljišč prisotnost bobra moteča. Včasih ljudje celo razdrejo bobrišča, ki segajo v/na kmetijsko zemljišče oz. podrejo njihove jezove. Razlog je, da bobri s svojo dejavnostjo lahko povzročajo gospodarsko škodo (objedanje obvodne drevnine, poljščin, poplave na obvodnih zemljiščih...) in da ljudje premalo poznajo njegovo pozitivno vlogo v ekosistemu (vzdrževanje in uravnavanje vodotokov, dvig podtalnice, oblikovanje mokrišč...). Drugi ukrep pa je povezan z izjemno obsežnim in težavnim ročnim odstranjevanjem ambrozije, ki se ga lastniki le redko lotijo.

Rezultati delavnic so bili upoštevani pri oblikovanju vizije, ciljev in usmeritev v upravljavskih načrtih za obe študijski območji. Z opisanim postopkom smo se približali mednarodnim priporočilom (Kovač in sod., 2017), ki izhajajo iz Aarhuške konvencije in drugih dokumentov, in sicer, da koordinacijo celotnega procesa načrtovanja vodi nevtralno delovno telo in da so v načrtovalski proces vključeni vsi relevantni deležniki, ki so v procesu načrtovanja enakovredni.

\section{POVZETEK}

\section{SUMMARY}

For Natura 2000 areas, the European Commission proposes the drafting of management plans that include site-specific objectives and conservation measures based thereon (European Commission, 2015). In order 
to avoid potential subsequent conflicts, the process needs to involve all stakeholders early on and in a sensible manner.

In the course of the creation of the Natura 2000 network, procedures differed significantly across member states depending on their respective administrative systems. For Slovenia, Boh (2005) found that the process was distinguished by a high degree of centralisation and technocratically guided decision-making processes. Data on the predicted Natura 2000 sites was not available to potential stakeholders, which is why they were not informed whether a given territory had been declared a Natura 2000 area until the end of the procedure, whereas broader opposing interests were not clearly articulated. Therefore, the establishment of Natura 2000 areas in Slovenia did not involve a participatory approach, which is why many advantages were missed.

In the framework of the GoForMura project, two draft management plans were drawn up for the forest areas of Gornja Bistrica and Murska Šuma, which are in a Natura 2000 area. In the process, great emphasis was placed on using a participatory approach, which was also utilised in the organisation of two project workshops.

The objective of the first workshop was to intensively solicit opinions, needs, and wishes from the stakeholders, and to coordinate them in drafting the management plans. The result was the identification of sets of measures and subordinate measures for improving the conservation status of selected forest habitat types and animal habitats. Based on these results, a questionnaire was prepared for assessing five sets of measures and five subordinate measures in each set. The questionnaire was tested on a small sample of stakeholders. After the deficiencies were remedied and the time frame adjusted, the questionnaire was ready for deployment at the workshop.

The objective of the second workshop was to evaluate the above-mentioned measures. The participants were divided into working groups comprising the representatives of different stakeholders (hunters, foresters, beekeepers, conservationists, etc.). We explained to them the purpose and structure of the questionnaire and the evaluation method, and we were available to provide any explanations regarding the questionnaire. The evaluation was conducted using the multi-criteria SMART decision method. This method was chosen because it is one of the simplest multi-criteria methods with which it is possible to directly compare the importance of the criteria. The stakeholders ranked the criteria from most to least important, whereupon they assigned the highest possible score to the most important criterion and successively lower scores to the remaining criteria. A scale with values from 1 to 10 was used since it is easier to understand for stakeholders unfamiliar with multi-criteria methods.

The results showed high support for forest restoration measures among all stakeholders, which was expected given that these measures are acceptable to forest owners, conservationists, and the general public. Measures to improve the conservation status of the analysed animal species received the lowest support. For the majority of the measures, the biggest differences were between forest owners, on one side, and the united group of nature conservationists and the general public, on the other. Forest owners, for example, strongly support the determination of the optimal or acceptable share of long-established non-native tree species (eastern black walnut, northern red oak, black locust, poplar clones), since these species are well represented in the area and managed by the owners. Conservationists and the general public, on the other hand, ranked this measure as the least important. Such a result was expected as it is clear from conservation guidelines that professionals in the field of nature conservation are in favour of reducing the share of longestablished non-native tree species. The stakeholder group comprising conservationists and the general public was also least supportive of the replacement of tree species with the aim of improving forest health.

The results of the workshop have already been incorporated into the vision, objectives, and guidelines contained in the management plans for both study areas. The procedure described marks a convergence with the international recommendations (Kovač et al., 2017) that follow from the Aarhus Convention and other documents in that the coordination of the entire planning procedure is managed by a neutral working body and that all relevant stakeholders - who have an equal status in the process - are involved in the planning process.

\section{ZAHVALA}

\section{ACKNOWLEDGEMENTS}

Prispevek je nastal v okviru mednarodnega projekta GoForMura »Upravljanje z izbranimi gozdnimi območji Natura 2000 ob Muri« (Program Norveškega finančnega mehanizma in Program Finančnega mehanizma EGP 2009-2014) ter Programskih skupin P40107 »Gozdna biologija, ekologija in tehnologija « in P4-0059 »Gozd, gozdarstvo in obnovljivi gozdni viri«, ki ju financira Javna agencija za raziskovalno dejavnost Republike Slovenije. 


\section{VIRI}

\section{REFERENCES}

Acosta M., Corral S. 2017. Multicriteria decision analysis and participatory decision support systems in forest management. Forests, 8, 4: 116.

Ananda J., Herath G. 2003a. Incorporating stakeholder values into regional forest planning: a value function approach. Ecological Economics, 45, 1: 75-90.

Ananda J., Herath G. 2003b. The use of analytic hierarchy process to incorporate stakeholder preferences into regional forest planning. Forest Policy and Economics, 5, 1: 13-26.

Barzilai J. 1997. Deriving weights from pairwise comparison matrices. Journal of the Operational Research Society, 48, 12: 12261232.Beierle T.C., Cayford J. 2002. Democracy in practice: public participation in environmental decisions. Resources for the Future: $160 \mathrm{str}$.

Bibič A. 2007. Program upravljanja območij Natura 2000: Operativni program 2007-2013. Ljubljana, Ministrstvo za okolje in prostor: 88 str.

Boh T. 2005. Implementacija habitatne direktive v Sloveniji primer vplivanja EU politik na nacionalno državo v procesu prilagajanja. Družboslovne razprave, 21, 48: 27-45.

Blagojević B., Jonsson R., Björheden R., Nordström E.-M., Lindroos O. 2019. Multi-criteria decision analysis (MCDA) in forest operations - an introductional review. Croatian Journal of Forest Engineering, 40, 1: 191-205.

Bryan B., Grandgirard A., Ward J. 2010. Quantifying and exploring strategic regional priorities for managing natural capital and ecosystem services given multiple stakeholder perspectives. Ecosystems, 13, 4: 539-555.

Chambers F.H., Beckley T. 2003. Public involvement in sustainable boreal forest management. V: Towards Sustainable Management of the Boreal Forest. Ottawa, Ontario, National research Council of Canada: 113-154.

Čater M. 2001. Vpliv svetlobe in podtalnice na naravno in umetno obnovo doba (Quercus robur L.) v nižinskem delu Slovenije (Murska šuma, Krakovski gozd): doktorsko delo. (Univerza v Ljubljani, Biotehniška fakulteta, Oddelek za gozdarstvo in obnovljive gozdne vire). Ljubljana, samozaložba: $182 \mathrm{str}$.

European Commission. 2015. Natura 2000 and Forests Part I-II. Technical Report - 2015-088. http://ec.europa.eu/environment/ nature/natura2000/management/docs/Final\%20Guide\%20 N2000\%20\%20Forests\%20Part\%20I-II-Annexes.pdf (10. 6. 2021).

European Commission. 2020. Pogosto zastavljena vprašanja o omrežju Natura 2000. https://ec.europa.eu/environment/nature/natura2000/faq_sl.htm (9.7.2021).

Edwards W. 1977. How to use multiattribute utility measurement for social decisionmaking. IEEE Transactions on Systems, Man, and Cybernetics, 7, 5: 326-340.

Edwards W., Barron F.H. 1994. SMARTS and SMARTER: improved simple methods for multiattribute utility measurement. Organizational Behavior and Human Decision Processes, 60, 3: 306-325.

Grošelj P., Hodges D.G., Zadnik Stirn L. 2016. Participatory and multicriteria analysis for forest (ecosystem) management: a case study of Pohorje, Slovenia. Forest Policy and Economics, 71: 80-86.

Grošelj P., Zadnik Stirn L. 2015. The environmental management problem of Pohorje, Slovenia: a new group approach within ANP - SWOT framework. Journal of Environmental Management, 161: 106-112.

Hiltunen V., Kurttila M., Leskinen P., Pasanen K., Pykäläinen J. 2009. Mesta: an internet-based decision-support application for participatory strategic-level natural resources planning. Forest Policy and Economics, 11, 1: 1-9.
Huber P., Hujala T., Kurttila M., Wolfslehner B., Vacik H. 2019. Application of multi criteria analysis methods for a participatory assessment of non-wood forest products in two European case studies. Forest Policy and Economics, 103: 103-111.

Kajanus M., Kangas J., Kurttila M. 2004. The use of value focused thinking and the A'WOT hybrid method in tourism management. Tourism Management, 25, 4: 499-506.

Kakoyannis C.A. 2001. Understanding the social acceptability of natural resource decisionmaking processes by using a knowledge base modeling approach. USDA Forest Service, General Technical Report PNW-GTR, 518: 40 str.

Kangas A., Laukkanen S., Kangas J. 2006. Social choice theory and its applications in sustainable forest management -a review. Forest Policy and Economics, 9, 1: 77-92.

Kelenc J. 2008. Zdravje nižinskih gozdov doba (Quercus robur L.) v GGE Ravensko: diplomsko delo. (Univerza v Ljubljani, Biotehniška fakulteta, Oddelek za gozdarstvo in obnovljive gozdne vire). Ljubljana, samozaložba: $97 \mathrm{str}$.

Khadka C., Hujala T., Wolfslehner B., Vacik H. 2013. Problem structuring in participatory forest planning. Forest Policy and Economics, 26, 1-11.

Kovač M., Kovač Š, Kutnar L., Mali B., Ferreira A. 2017. Znanstvene, strokovne in politične podlage za izdelavo upravljavskih načrtov za gozdna območja Natura 2000. V: Kovač M., Ferreira A. (ur.). Vzorčni upravljavski načrt za gozdna območja Natura 2000: primer poplavnih gozdov ob Muri. Ljubljana, Gozdarski inštitut Slovenije: A1-A7.

Kutnar L., Marinšek A. 2016. Stanje raziskovalnih gozdnih habitatnih tipov ob Muri. V: Ferreira A., Planinšek Š. (ur.). GoforMura: upravljanje gozdnih habitatnih tipov in vrst v izbranih območjih Natura 2000 ob Muri. Ljubljana.Silva Slovenica, Gozdarski inštitut Slovenije: 4-9.

Levanič T. 1993. Vpliv melioracij na debelinsko rast in prirastek črne jelše, ozkolistnega jesena in doba v Prekmurju. Zbornik gozdarstva in lesarstva, 42: 7-65.

Macpherson H. 2004. Participation, practitioners and power: community participation in north east community forests. Newcastle upon Tyne, Office of the Deputy Prime Minister, Economic and Social Research Council: 64 str.

Mendoza G.A., Prabhu R. 2005. Combining participatory modeling and multi-criteria analysis for community-based forest management. Forest Ecology and Management, 207,1-2: 145-156.

Mendoza G.A., Prabhu R. 2006. Participatory modeling and analysis for sustainable forest management: overview of soft system dynamics models and applications. Forest Policy and Economics, 9, 2: 179-196.

Nordström E.-M. 2010. Integrating multiple criteria decision analysis into participatory forest planning: PhD thesis. (Swedish University of Agricultural Sciences). Umeå: $70 \mathrm{str}$.

Nordström E.-M., Eriksson L.O., Öhman K. 2010. Integrating multiple criteria decision analysis in participatory forest planning: experience from a case study in northern Sweden. Forest Policy and Economics, 12, 8: 562-574.

Nordström E.-M., Holmström H., Öhman K. 2013. Evaluating continuous cover forestry based on the forest owner's objectives by combining scenario analysis and multiple criteria decision analysis. Silva Fennica, 47, 4: 1-22.

Ortiz-Urbina E., González-Pachón J., Diaz-Balteiro L. 2019. Decisionmaking in forestry: a review of the hybridisation of multiple criteria and group decision-making methods. Forests, 10, 5: 375.

Participativne delavnice na temo obnove dolgoročnih lovsko upravljavskih načrtov po lovsko upravljavskih območjih. 2021. http://www.zgs.si/aktualno/novice/news_article/v_juniju_in_ juliju_bodo_organizirane_i_participativne_delavnice_na_temo_ obnove_dolgorocni_777/index.html (10.7. 2021). 
Pavlikakis G.E., Tsihrintzis V.A. 2003. A quantitative method for accounting human opinion, preferences and perceptions in ecosystem management. Journal of Environmental Management, 68, 2: 193-205.

Pezdevšek Malovrh Š., Kurttila M., Hujala T., Kärkkäinen L., Leban V. in sod. 2016. Decision support framework for evaluating the operational environment of forest bioenergy production and use: case of four European countries. Journal of Environmental Management, 180, 68-81.

Reed M.S. 2008. Stakeholder participation for environmental management: a literature review. Biological Conservation, 141, 10: 2417-2431.

Rowe G., Frewer L.J. 2000. Public participation methods: a framework for evaluation. Science, Technology \& Human Values, 25, 1: 3-29.

Sheppard S.R.J, Achiam C.M. 2004. Public participation in forest decison making: V: Encyclopedia of forest science. Oxford, San Diego, Elsevier: 1173-1182.

Sheppard S.R.J., Meitner M. 2005. Using multi-criteria analysis and visualisation for sustainable forest management planning with stakeholder groups. Forest Ecology and Management, 207, 1-2: 171-187.
Uhde B., Andreas Hahn W., Griess V.C., Knoke T. 2015. Hybrid MCDA methods to integrate multiple ecosystem services in forest management planning: a critical review. Environmental Management, 56, 2: 373-388.

von Winterfeldt D., Edwards W. 1986. Decision Analysis and Behavioral Research. Cambridge, Cambridge University Press: 604 str.

Zandebasiri M., Pourhashemi M. 2016. The place of AHP method among multi criteria decision making methods in forest management. International Journal of Applied Operational Research, 6, 2: 75-89.

ZRSVN. 2013. Poročilo o stanju ohranjenosti habitatnih tipov 20022012. https://zrsvn-varstvonarave.si/informacije-za-uporabnike/katalog-informacij-javnega-znacaja/porocanje-po-17-clenudirektive-o-habitatih/ (9. 7. 2021).

ZRSVN. 2019. Poročilo o stanju ohranjenosti habitatnih tipov 20132018. https://zrsvn-varstvonarave.si/informacije-za-uporabnike/katalog-informacij-javnega-znacaja/porocanje-po-17-clenudirektive-o-habitatih/ (9. 7. 2021). 